\title{
Evaluation of in-vitro Anthelmintic Activity of Ximenia america- na, Hopea ponga and Vitex leucoxylon
}

\author{
Arun Kashivishwanath Shettar and Ankala Basappa Vedamurthy*
}

\section{Arun Kashivishwanath Shettar and Ankala Basappa Vedamur- thy* \\ P G Department of Studies in Biotech- nology and Microbiology, Karnataka University, Dharwad 580003, Karnataka, INDIA. \\ Correspondence}

Dr.Ankala Basappa Vedamurthy

\section{Professor and Chairman}

Department of Biotechnology and $\mathrm{Mi}$ crobiology, Karnataka University, Dharwad-580003, Karnataka, INDIA.

Phone no: +91-9341314101

E-mail: vedamurthybt@gmail.com

History

- Submission Date: 26-12-16;

- Review completed: 05-01-17;

- Accepted Date: 02-02-17.

DOI : 10.5530/pj.2017.3.62

Article Available online http://www.phcogj.com/v9/i3

\section{Copyright}

(C) 2017 Phcog.Net. This is an openaccess article distributed under the terms of the Creative Commons Attribution 4.0 International license.

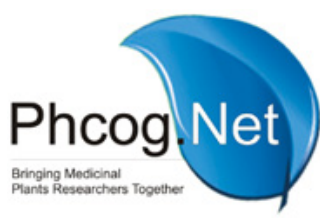

\begin{abstract}
Objective: Evaluating Anthelmintic activity of Ximenia americana, Hopea ponga and Vitex leucoxylon extracts by using in vitro assay. Methods: The serial exhaustive extraction was carried out with a series of solvents: chloroform, ethyl acetate, methanol, ethanol and water with increasing polarity using Soxhlet apparatus. The concentrated and dried extracts were evaluated for anthelmintic activity by employing standard in vitro method (Pheretima Posthuma model). Results: In vitro anthelmintic study shows that in case of Ximenia americana chloroform extract showed higher anthelmintic activity where as incase of Hopea ponga and Vitex leucoxylon methanol extract exhibited significant activity when compared to other solvent extracts. Conclusion: Results confirm that methanol extract of Hopea ponga exhibited highest anthelmintic activity among all tested extracts. This study provides scientific evidence that the leaves of Ximenia americana, Hopea ponga and Vitex leucoxylon have anthelmintic efficacy. However further comprehensive chemical and pharmacological investigation should be carried out to isolate the active compounds and appropriate elucidation of its mechanism of action and it helps in the development of new pharmaceuticals to treat Helminthiasis.
\end{abstract}

Key words: Ximenia americana, Hopea ponga, Vitex leucoxylon, Pheretima Posthuma model, in vitro anthelmintic activity.

\section{INTRODUCTION}

Helminthiasis is an infection disease caused by nematode worms such as Ascaris lumbricoides, Trichuris trichiura, Nectator americanus and Ancyclostoma duodenale. Infection occurred when ingesting food contaminated eggs or larvae, hands or utensils or through penetration of the skin by infective hookworm larvae in contaminated soil. ${ }^{1}$ According World Health Organization (WHO) estimation more than 1.5 billion (24\%) of world population are infected by parasitic worms. The parasite worm infection cases are commonly occurred in tropic and sub tropic regions with most cases in Africa, America, China and Southeast Asia. ${ }^{2}$ Lack of adequate sanitary facilities and supply of pure water coupled with poverty and illiteracy are some of the factors responsible for wide spread nature of this disease in the developing countries. In developing countries these parasite infections became threat to society by causing severe morbidity, including lymphatic filariasis, onchosorciasis and schistomomiasis. ${ }^{3}$ As per World Health Organization (WHO), only few drugs are frequently used in the treatment of parasitic infections. ${ }^{4}$ Anthelmintic drugs can be classified according to their chemical structure as well as their specific action towards specific type of the helminthes. ${ }^{5}$ Because of the increasing toxicity and allergic manifestations of anthelmintic drugs the gastrointestinal helminthes became resistant to current available synthetic anthelmintic drugs ${ }^{6,7}$ From ancient time medicinal plants play important role in the elimination of soil transmitted Helminthiasis. Natural products based drugs have used against various diseases since time immemorial. Plant derived natural products hold great promise for the discovery and development of new drugs. Medicinal plants provided with secondary metabolites usually called as phytochemicals or bioactive compounds which are considered as natural source of antioxidant, antimicrobial and anti-inflammatory agents which have been shown to reduce the risk and progression of many diseases such as cancer and diabetes ${ }^{8,9}$ and also many plants have been used to treat parasitic infections in humans and animals. ${ }^{10-13}$ In the present study, Ximenia americana, Hopea ponga and Vitex leucoxylon plants were selected for in vitro anthelmintic study. Ximenia americana Linn. Plant belonging to Olacaceae family was selected. X. americana is a small tree or shrub, native to tropical area of Africa and seen distributed in many parts of the world. This species is used in treatment of wide variety of ailments by many rural communities in Africa and Asia. This is commonly known as wild olive or sour plum or yellow plum and extensively used as herbal remedy in treatment of malaria, leproutic ulcer, and skin infection. ${ }^{14}$ The leaves are reported to have antibacterial activity and also used in the treatment of fever, tuberculosis, tooth decay and wounds. ${ }^{15}$ Hopea ponga is an endemic tree belonging to Dipterocapaceae family found in tropical ever green forest of western India and it is widely distributed along the Western Ghat of Karnataka. ${ }^{16}$ $H$.ponga is categorized as an endangered tree spe- 
cies under the International Union for Conversation of Nature Red List of threatened species. This plant was reported to be used as traditional medicine in the treatment of piles and snake bite. ${ }^{17}$ Bark of Hopea ponga is known to have high content of tannin and acts as astringent. ${ }^{18}$ Vitex leucoxylon is commonly known as five leaved chaste tree and belongs to the verbenaceae family. It is small to large deciduous tree, growing up to $20 \mathrm{~m}$ in height. It is widely distributed along the Western Ghats of India. The leaves of V.leucoxylon are reported to have medicinal properties like relieving headache, fever and catarrh. ${ }^{19}$ Reports indicate that aqueous and ethanolic extracts of V.leucoxylon leaves possess antipsychotic, antidepressant, analgesic, anti-inflammatory, anti-parkinsonian and antimicrobial activities. ${ }^{20,21}$ However these three above mentioned plants have not been subjected for investigation for their anthelmintic activity. With this background, the present study was undertaken to evaluate anthelmintic properties of Ximenia americana, Hopea ponga and Vitex leucoxylon.

\section{MATERIALS AND METHODS}

\section{Plant collection}

Leaves of Ximenia americana, Hopea ponga and Vitex leucoxylon were collected from Anashi forest range of Western Ghats, Uttar Kannada District, Karnataka, India during the period of May, 2015. The leaves were identified and authenticated by Dr. Kotresha K, Dept of Botany, Karnatak Science College, Dharwad; Karnataka by referring to the voucher specimen deposited in the Dept of Botany, Karnatak Science College, Dharwad, Karnataka. Fresh plant leaves material was collected and washed under running tap water, shade dried and then homogenized to coarsely powder. The powder was stored in airtight containers at $-20{ }^{\circ} \mathrm{C}$ for further use for crude solvent extraction.

Drugs and chemicals

All the solvents, chemicals and the standard drug Piperazine citrate (SD Fine Chemicals Ltd., Mumbai).

\section{Crude Extraction}

Coarsely powdered dried leaves of Ximenia americana, Hopea ponga and Vitex leucoxylon (100g each) were subjected to successive solvent extraction using soxhlet apparatus separately. The extraction of each plant leaves material was done with different solvents in their increasing order of polarity which includes chloroform, ethyl acetate, methanol, ethanol and distilled water. Each time the plant material was dried and later extracted with next high polar solvents (following the strategy of extraction in series of increasing the solvent polarity). All extracts were concentrated in Buchi rotary evaporator, followed by removal of traces of solvent by using desiccator.

\section{Test organism}

Indian adult earthworms (Pheretima posthuma) collected from the University of Agriculture Sciences, Dharwad, India. The earthworms were maintained under normal vermicomposting medium with adequate supply of nourishment and water. Before the initiation of experiment the earthworms were washed with normal saline. Adult earthworms of approximately $4 \mathrm{~cm}$ in length and $0.2-0.3 \mathrm{~cm}$ in width were used for the experiment. This organism was selected model for anthelmintic activity due to its anatomical and physiological resemblance with the intestinal roundworm parasites of human beings. ${ }^{22,23}$

\section{Extract preparation for experiment}

The porously powdered plants material was used for extract preparation. After extraction, the crude extract was stored in desiccator until further use. Each solvent extracts and standard drug Piperazine citrate were dis- solved in $0.5 \%$ DMSO in normal saline $(\mathrm{v} / \mathrm{v})$. Whereas, the crude aqueous extract of all plants was directly dissolved in normal saline and used for evaluation for anthelmintic activity.

\section{Anthelmintic activity}

The anthelmintic activity of Ximenia americana, Hopea ponga and Vitex leucoxylon extracts was evaluated by the following the method of Dash et al. ${ }^{24}$ For each plant Twenty seven groups of animals with three earthworms in each groups, each earthworm were separate released into 20 $\mathrm{ml}$ of desired formulation in normal saline, Group 1 earthworm were released in $20 \mathrm{ml}$ normal saline in a clean Petri plate. Group 2, 3, 4, 5, 6 earthworms were released in $20 \mathrm{ml}$ normal saline containing 50, 100, 150,200 and $250 \mathrm{mg} / \mathrm{ml}$ of chloroform extract respectively. Similarly, group $7,8,9,10,11$ earthworms were released in $20 \mathrm{ml}$ normal saline containing 50,100, 150, 200 and $250 \mathrm{mg} / \mathrm{ml}$ of ethyl acetate extract respectively. Same thing will be followed for methanol, ethanol and aqueous extracts for each plant till reach of group 26. Group 27 earthworms were released in $20 \mathrm{ml}$ normal saline containing standard drug piperazine citrate $(100 \mathrm{mg} / \mathrm{ml})$. Earthworms were observed; the time taken for paralysis and the time taken for death was monitored and documented in minutes. Paralysis time was analyzed based on the behavior of the earthworm with no revival body state in normal saline medium. Death was concluded based on total loss of motility with faded body color. ${ }^{25}$

\section{Statistical analysis}

All experiments were performed in triplicates $(n=3)$ and the data are presented as the mean \pm standard error. Differences between the means of the individual groups were analyzed using the analysis of variance procedure of SPSS software 20 Version (IBM). The significance of differences was defined at the $\mathrm{p}<0.05$ and $\mathrm{p}<0.01$ level.

\section{RESULTS AND DISCUSSION}

Helminthes are classified as eukaryotic endoparasites because they live inside the body, unlike parasites like lice and fleas that live outside their host. Most diseases caused by helminthes are of chronic in nature they probably cause more morbidity and greater economic and social deprivation among humans and animals. Especially in the India incidence of these diseases is at high rate especially during wet seasons with high as $100 \%$ incidence. In the India many anthelmintic drugs are available in market but these are of high cost and limited effective control over parasitic infections. ${ }^{26,27}$ Plant products are frequently considered to be less toxic and significantly free from side effects than synthetic ones. ${ }^{28}$ In the present study the concentrated and dried extracts Ximenia americana, Hopea ponga and Vitex leucoxylon were evaluated for in vitro anthelmintic activity by varying the concentration $(50-250 \mathrm{mg} / 20 \mathrm{ml})$ with using Indian earth worm (Pheretima posthuma) as animal model. In case of Ximenia americana many investigations have validated the use of roots in the treatment of leprosy, syphilis, dysentery, and wounds. The stem bark has been reported to have anti-trypanosmal activity. The root bark and leaf of Ximenia americana is used as herbal medication for the cure of many ailments by Northern part of Nigeria. ${ }^{29}$ In our previous studies the aqueous and methanolic leaf extracts of $X$. americana showed significant antioxidant and anti-inflammatory activities. ${ }^{30}$ In the present study among different solvent extracts of Ximenia americana chloroform extract exhibited highest anthelmintic activity with paralysis time 24.66 $\pm 1.20185(\mathrm{~min})$ and death time of $39.66 \pm 0.88192(\mathrm{~min})$ and it was compared with standard drug Piperazine citrate (shown in Figure 1). The anthelmintic activity of remaining extracts was depicted in Table 1. In case of Hopea ponga and Vitex leucoxylon among five solvent extracts methanol extract of Hopea ponga showed very good and significant anthelmintic activity on comparison with other tested extracts with paralysis time 


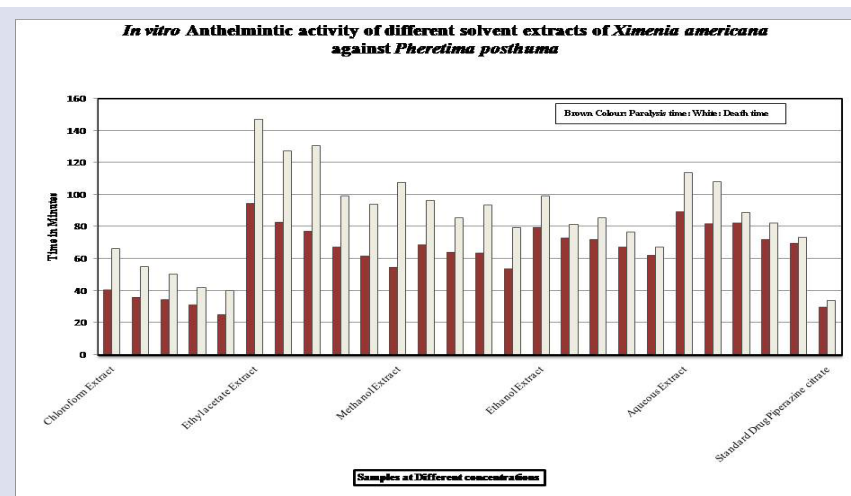

Figure 1: In vitro Anthelmintic activity of different solvent extracts of Ximenia americana against Pheretima posthuma

In vitro Anthelmintic activity of different solvent extracts of Hopea ponga against Pheretima posthuma

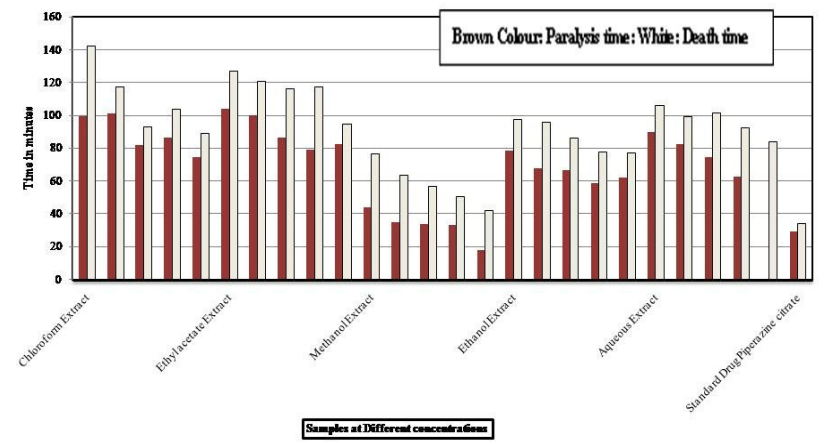

Figure 2: In vitro Anthelmintic activity of different solvent extracts of Hopea ponga against Pheretima posthuma

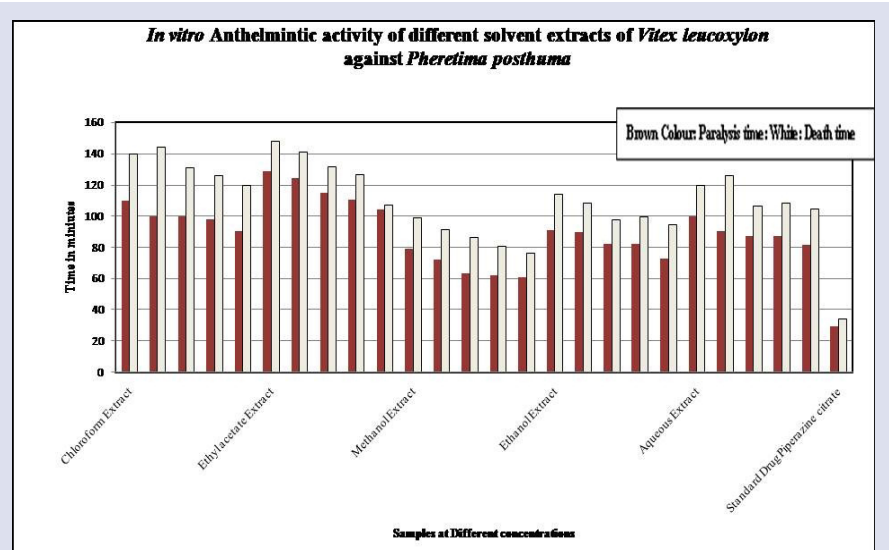

Figure 3: In vitro Anthelmintic activity of different solvent extracts of Vitex leucoxylon against Pheretima posthuma

$18.33 \pm 1.45297(\mathrm{~min})$ and death time of $42.00 \pm 2.30940$ at $250 \mathrm{mg} / 20 \mathrm{ml}$ concentration and other remaining extracts not shown promising activity and the results are shown in Table 2 and Figure 2 and the results of tested extracts of Vitex leucoxylon are shown in Table 3 and Figure 3. Even in many previous studies methanol extract of these both plants possess several biological activities i.e. methanolic extract of seed wings of Hopea ponga exhibits antioxidant and antibacterial activity. ${ }^{31}$ Even the root and bark of V.leucoxylon are reported to use as astringent and febrifuge. ${ }^{32}$ Many hepatoprotective agents were isolated from leaves and bark of V.leucoxylon which includes $\beta$-sitosterol, vitexin, isovitexin and aucubin. ${ }^{33}$ The results indicate that All medicinal plants and their extracts cannot exhibit anthelmintic activity in the present study also among three plants with twenty five solvent extracts only methanol extract of Hopea ponga and chloroform extract of Ximenia americana shown appreciable anthelmintic activity in performed in-vitro assay where as other tested extracts showed the least anthelmintic activity. These results correlating with the recent work has been done on anthelmintic activity of Artabotrys hexapetalus (Linn.f) and Kalanchoe pinnata. ${ }^{34,35}$

\section{CONCLUSION}

In the present study in performed in-vitro method for anthelmintic activity shows that all the tested extracts of Ximenia americana, Hopea pon$g a$ and Vitex leucoxylon showed anthelmintic activities but among tested extracts methanol extract of Hopea ponga and chloroform extract of $\mathrm{Xi}$ menia americana exhibited higher anthelmintic activity over all extracts with good timing for both paralysis and Death time. At the concentration $250 \mathrm{mg} / 20 \mathrm{ml}$ Chloroform extract of Ximenia americana taken 24.66 min to cause paralysis in Pheretima posthuma whereas methanol extract of Hopea ponga taken 18.33 min but standard drug Piperazine citrate taken $29.33 \mathrm{~min}$ at $100 \mathrm{mg} / 20 \mathrm{ml}$ concentration. In case of causing death in Pheretima posthuma both chloroform extract of Ximenia americana and methanol extract of Hopea ponga taken almost nearest timing i.e. $39.66 \mathrm{~min}$ and $42 \mathrm{~min}$ respectively. Based on the present study results it can be used for the development of new pharmaceutical drugs for treatment and curing of Helminthiasis and also this study shows that these extracts offer a safe method or supplement treatment strategy to control Helminthiasis. However further comprehensive chemical and pharmacological investigation should be carried out to isolate the active compounds and appropriate elucidation of its mechanism of action and it helps in the development of new pharmaceuticals to treat Helminthiasis.

\section{ACKNOWLEDGEMENT}

The authors would like to thank Department of Biotechnology and Microbiology, Karnataka University, Dharwad, Karnataka, India for providing necessary facilities and laboratory for doing this research work.

\section{CONFLICT OF INTEREST}

We wish to confirm that there are no known conflicts of interest associated with this publication.

\section{ABBREVIATIONS USED}

\%: Percentage; g: Gram; mg: Milligram; ml: Milliliter; min: Minutes; cm: Centimeter

\section{REFERENCES}

1. WHO, Epidemiology of Soil-Transmitted Helminthiases, Geneva: WHO, 2011, [Online] Available from: http://www.who.int/intestinal_worms/epidemiology. en/ [Accessed on $5^{\text {th }}$ May, 2014].

2. WHO, Media Centre: Soil-Transmitted Helminth Infections [Internet], Geneva: WHO, 2014, [Online] Available from: http://www.who.int/mediacentre/factsheets/fs366/en/ [Accessed on $5^{\text {th }}$ May, 2014].

3. Tripathi KD, Essentials of Medical Pharmacology, 6 ${ }^{\text {th }}$ Ed., Jaypee Brothers Medical Publishers, (P) Ltd. New Delhi (2008). https://doi.org/10.5005/jp/ books/10282.

4. Aswar Manoj, Aswar Urmila and Watkar Bhagyashri. Int J Green Pharm. 2008;170-73.

5. Rao, Chawathe and Shah. An Introduction to Synthetic Drugs and Dyes Second Edition, Himalaya Publishing House (June 1995) pp. 50-3.

6. Singh D, Swarnkar CP, Khan FA. Anthelmintic resistance in Gastrointestinal nematodes in livestock in India. J Vet Parasit. 2002;16;115-30.

7. Tuse TA; Bidkar AA; Bhale SA, Patanka RD. In-vitro anthelmintic activity of aerial roots of ficus benghalensis. International Journal of Pharmacological Research. 2011;1(1):10-13. https://doi.org/10.7439/ijpr.v1i1.147. 
8. Ali SS, Kasoju N, Luthra A, Singh A, Sharanabasava H, Sahu A, et al. Indian medicinal herbs as sources of antioxidants. Food Res Int. 2008;41(1):1-15. https:// doi.org/10.1016/j.foodres.2007.10.001.

9. Pham-Huy LA, He H, Huyc CP. Free radicals, antioxidants in disease and health. Int J Biomed Sci. 2008;4(2):89-96. PMid:23675073 PMCid:PMC3614697.

10. Nadkarni, AK. Indian Materia Medica. 3rd Ed. Popular Prakashan, Bombay, India.1954. PMid:13199797

11. Chopra RN, Nayyar SL, Chopra IC. Glossary of Indian Medicinal Plants.Counci of Scientific and Industrial Research. 1956:160

12. Said M. Hamdard Pharmacopea of Eastern Medicine. Hamdard National Foundation, Karachi, Pakistan; 1969

13. Akhtar, MS, Iqbal Z, Khan MN Lateef M, Anthelmintic activity of medicina plants with particular reference to their use in animals in Indo-Pakistan subcontinent. Small Ruminants Res. 2000;38:99-107. https://doi.org/10.1016/S09214488(00)00163-2

14. Cristina Voss, Ergul Eyol, Martin R, Berger. Unit of Toxicology and Chemotherapy, Deutsches Krebsforschungszentrum Heidelberg, E100, Im Neuenheimer Feld 280, 69120

15. Ogunyleye DS, Ibitoye SF. Studies of antimicrobial activity and chemical constituents of Ximenia americana. Tropical Journal Pharmacology Research. 2003;2:239-41.

16. Shiddamallayya N, Azra Y, Gopakumar K. Medico botanical survey parvatha kkuke subramanaya mangalore karnatak. Indian J Tradi Med. 2008;9(1):96-9.

17. Muralikrishnan $\mathrm{H}$, Chandrashekar KR. Regeneration of Hopea ponga: influence of wing loading and viability of seeds. J Trop For Sci. 1997;10:58-65.

18. Shivaprasad PV, Vasanthraj BK, Chandrashekar KR. Dipterocarps of the Western Ghats of Karnataka. Indian J Forest. 1999:9:201-6.

19. Chanda YR. The wealth of India:A dictionary of Indian Raw materials and Industrial products; Publication and Information Directorate, CSIR, New Delhi. 1982: pp:520-1.

20. Makwana HG, Ravishankar B, Shukla VJ, Vijayan NP, Sasikala CK, Saraswathy VN and Bhatt SV. General pharmacology of Vitex leucoxylon linn leaves. Indian J Physiol Pharmacol. 1994;38:95-100. PMid:8063369.

21. Sarma SP, Aithal KS, Srinivasan KK, Udupa AL, Kumar V, Kulkarni DR and Rajagopal, PK. Anti-inflammatory and wound healing activities of the crude alcoholic extract and flavonoids of Vitex leucoxylon. Fitoterapia. 1990;61(3):263-5.

22. Thorn GW, Adams RD, Braunwald E, Isselbacher KJ and Petersdrof RG Harrison's Principles of Internal Medicine. In: Mcgraw Hill Co., New York: 1977;1088-9. PMCid:PMC2441402.
23. Vigar Z. Atlas of Medical Parasitology. In: $2^{\text {nd }}$ ed. P.G. Publishing House, Singapore: 1984;216-7.

24. Dash GK, Suresh P, Kar DM, Ganpaty S, Panda SB. Evaluation of Evolvulus alsinoids Linn for anthelmintic and antimicrobial activities. J. Nat. Rem. 2002;2:182-5

25. Tambe VD, Nirmal SA, Jadhav RS, Ghogare PB and Bhalke RD. Anthelmintic activity of Wedelia trilobata leaves. Indian J. Nat. Prod. 2006;22:27-9.

26. Asolkar LV, Kakkar KK, Chakre OJ. Second supplement to Glossary of Indian Medicinal Plants with Active Principles. CSIR Publication. New Delhi.1992, 61.

27. Kritikar KR, Basu LM. Indian Medicinal plants.2000;841-3.

28. Dhandapani S, Vijayakumar R, Senthilkumar R, Nalini N. Hypolipidemic effect of Cuminum cyminum on alloxan-induced diabetic rats. Pharmacol Res 2002;46(3):251-5. https://doi.org/10.1016/S1043-6618(02)00131-7.

29. Maikai VA, Nok AJ, Alawa C. In vitro anti-trypanosomal activity of aqueous and methanolic crude extract of stem bark of Ximenia americana on Trypanosoma congolense. Africa journal of Biotechnology. 2008;2(3):55-8.

30. Arun KS, Kotresha K, Kaliwal BB, Vedamurthy AB. Evaluation of in vitro antioxidant and anti-inflammatory activities of Ximenia americana extracts Asian Pac Trop Dis. 2015;5(11):918-23

31. Sukesh Syed Hidayath, Haneef M, Arunkumar K, Chandrashekar KR. Phy tochemical evaluation, antioxidant and antibacterial activity of seed wings of Hopea ponga (Dennst). Mabberly. Int J Pharm Pharm Sci. 2011;4(8):2593-5.

32. Meena R, Santhana Kumar G, Asir Selin, Kumar R. Ethnomedicinal shrubs of Marunduvalmalai, western Ghats, Tamilnadu, India. J Basic Applied Bio. 2009;3(1\&2):67-70

33. Rao RVK, SatyanarayanaT and Jena R. Phytochemical studies on Vitex leucoxyIon L. Indian Drugs. 1997;34(1):50-1.

34. Vasundhara M, Karthik YP, Anjali KR, Chithra C, Gupta P, Roopa C. Absence of anthelmintic activity of hydroalcoholic leaf extracts of Artabotrys hexapetalus (Linn.f). J Pharm Negative Results. 2014;5(1):1-3. https://doi.org/10.4103/09769234.136770.

35. Phatak RS. Lack of anthelmintic activity of Kalanchoe pinnata fresh leaves J Pharm Negative Results. 2016;7(1):21-4. https://doi.org/10.4103/09769234.177056

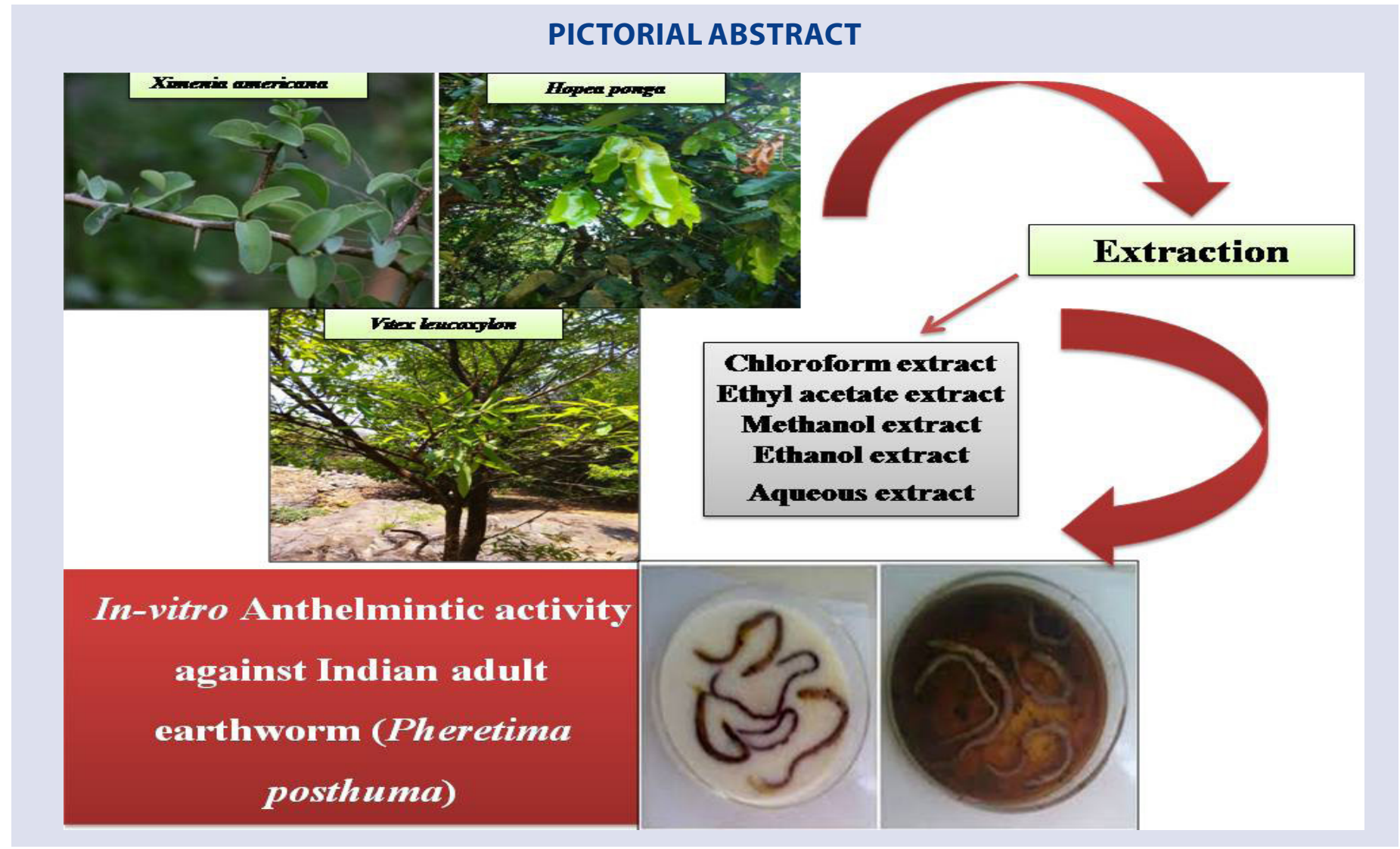




\section{SUMMARY}

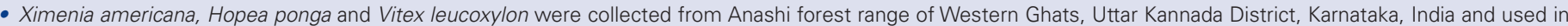
the traditional medicine.

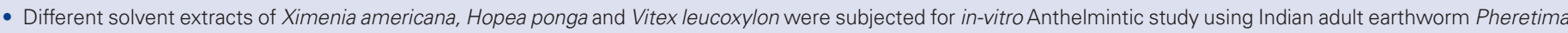
posthuma as an animal model.

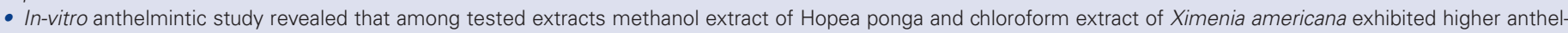
mintic activity over all extracts.

- However further study is needed for purification and isolation of active compounds from selected extracts which may serve as potential drug to treat Helminthiasis.

\section{ABOUT AUTHORS}

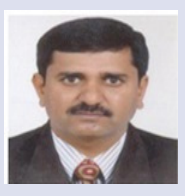

Dr. A B Vedamurthy: Obtained his M.Sc., M.B.Tech., Ph.D de $\neg$ gree from Gulbarga University, Gulbarga in 1999. He started his career as a Guest lecturer in Gulbarga University, Gulbarga in 1996. Thereafter he joined The Oxford College of Science as lecturer in 2000. During his tenure in The Oxford College of Science till October 2013 he has served in several important positions namely Reader, Professor \& Head of Biotechnology Department and Principal. He has created a productive learning en-vironment that is student-centered. He joined Department of Biotechnology and Microbiology, Karnatak University, Dhar $\neg$ wad in November 2013. His specialization includes Genetic Engineering, Molecular Biology, Plant Biotechnology, Agricultural Biotechnology, Medicinal and Aromatic plants, Bioactive compounds, Microbial \& Plant Pathology/Mycology.

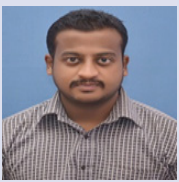

Mr. Arun K Shettar: Arun Shettar is a doctoral student at Karnataka University, Dharwad. He has done his masters from Karnatak University and His research area includes Plant Biotechnology, Natural products, Phytochemistry.

Cite this Article: Shettar AK, Vedamurthy AB. Evaluation of in-vitro Anthelmintic Activity of Ximenia Americana, Hopea ponga and Vitex leucoxylon. Pharmacogn J. 2017;9(3):367-71. 